Valentyna Mamonova ${ }^{1}$, Vira Kojurina ${ }^{2}$

\title{
LAND RESOURCES ADMINISTRATION IN UKRAINE: IMPLEMENTATION OF A THREE-TIER MODEL OF POWER DISTRIBUTION
}

Keywords: land decentralization, structure of local executive authorities, distribution of powers, community land resources, land management, sociological survey.

ABSTRACT: The article provides a scientific analysis of the regulation of the powers of district
state administrations in the field of land management. It was determined that the normative
securing of the functions of the district authorities in land management, as well as the regulation
of environmental safety requires unification, since in the basic laws the norms differ in content
and formulation. These powers need to be reflected in the structure of the district state admini-
stration, in accordance with the basic law of administration (the structure of the public autho-
rity must correspond to the functions). In order to study the practice, the structure of 40 district
administrations of different regions of Ukraine was analyzed; it was found that the actual struc-
ture does not correspond to the functional load, which is enshrined in the legislation. It is such
inconsistencies that make it impossible to move to the second stage of decentralization, which
is already taking place at the legislative level.
A scientific analysis of the results of the survey of officials of district and local authorities
was carried out. The survey was conducted in the districts that were among the first to comple-
te the process of uniting territorial communities. The topic of the survey was the distribution of

1 Doctor of Public Administration, Professor, Professor at the Department of Regional Development and Local Government, Kharkiv Regional Institute of Public Administration of National Academy of Public Administration attached to the Office of the President of Ukraine, v.mamonova1005@gmail.com. ORCID: 0000-0002-0219-3884

2 Postgraduate Student at the Department of Regional Development and Local Government, Kharkiv Regional Institute of Public Administration of National Academy of Public Administration attached to the Office of the President of Ukraine, gubska@ukr. net. ORCID: 0000-0001-5475-675X 
powers and responsibilities in various areas, in particular in the field of land relations and environmental issues. It has been established that there is a general tendency to the blurring of the district level of power, since the bulk of powers was given to local governments. A number of functions (control) have been considered expedient to perform together by employees of both structures. The problems that may arise in the cooperation of DSA and local governments in the outlined area have been considered. Approaches to the distribution of powers depending on the stage of land decentralization implementation and the role of DSA in each of the two proposed administration models have been analyzed. Relevant changes to the regulatory framework have been proposed and directions for further research have been indicated.

\section{INTRODUCTION}

One of the central problems of any reform related to the redistribution of powers between local executive authorities and local governments is to avoid functions duplication and / or gaps in their securing. That is why the changes should take place in a systematic way and must be scientifically grounded, because it is the distribution of functions that the structure of the government or local government, the quality of providing administrative services and, as a result the satisfaction of the needs of the citizens and the well-being of the community, region, country as a whole will depend on.

Today, several key reforms in the public administration system in Ukraine are in a mobile stage of implementation, namely: land, administrative and territorial structure reform, in addition, the land market is being actively formed. Each of these reforms introduces fundamental changes to the land administration system. It is the processes of active transformations and the search for an optimal administration model that emphasize the relevance of the topic of distribution of powers based on theory generalization and practice analysis. Since in order to ensure the complexity of research and reliability of conclusions and recommendations it is necessary to study not only current legislation but also the real situation with the transfer of functionality, change of the form of land ownership, etc.

At the present stage, the system of land relations requires special attention, because the construction of the land market and expanding the powers of local governments are designed to improve the quality of 
management decisions, but they also carry certain challenges: staff shortage in local governments, lack of competent officials in relevant fields; the presence of a state monopoly (and in fact - an oligopoly of individual business groups) on land management, which entails corruption risks, etc.

The purpose of the article is to substantiate the expedience of introducing a three-tier model of distribution of powers of public administration bodies in land management on the basis of scientific and applied analysis of the normative securing the functions of district state administrations in this area.

\section{LEGISLATIVE REGULATION OF THE DISTRIBUTION OF POWERS FOR LAND MANAGEMENT}

According to the current legislation, the management of land resources of territorial communities is attributed to the competence of: local governments (hereinafter -LG); district state administrations (hereinafter - DSA); territorial bodies of the State Service of Ukraine on Geodesy, Cartography and Cadastre (regional departments of the State Geocadastre). In the context of land decentralization, functions are being redistributed; powers and even the form of ownership of agricultural land outside settlements (from state to communal) are changed, which leads to the so-called "blurring " of the district level of land management. That is why DSAs require special attention being local executive bodies of general competence, subjects of public administration, whose scope of powers is changing dynamically.

The functions of local state administrations in the outlined area are enshrined in two legislative acts: the Land Code of Ukraine and the Law of Ukraine "On Local State Administrations" (Zemel'nyj kodeks Ukrainy: Zakon Ukrainy vid 25.10.2001, No. 2768-III; Pro mistsevi derzhavni: Zakon Ukrainy vid 09.04.1999, No. 586-XIV). Moreover, some of the powers defined in them coincide, for example:

- control of state-owned lands within the limits determined by the Land Code of Ukraine (it controls state-owned lands in accordance with the law); 
- participation in the development and implementation of national and regional (republican) programs on land use and protection (develops and ensures the implementation of legally approved programs for the rational use of land, forests, increasing the fertility of soils which are in state ownership);

- coordination of implementing land management and state control over land use and protection (coordinates land management documentation in cases and in the manner prescribed by the Land Code of Ukraine and the Law of Ukraine "On Land Management" on compliance of specified documentation with legislation in the field of environmental protection);

- submission to the Cabinet of Ministers of Ukraine of proposals on establishing and changing the boundaries of districts, cities in the manner prescribed by law (submitting proposals to the Cabinet of Ministers of Ukraine on establishing and changing the boundaries of districts, cities in the manner prescribed by law).

According to the Law of Ukraine "On Local State Administrations", the use of land, natural resources, environmental protection is attributed to the powers of the administration, in addition, this law establishes a list of powers in the sphere. But at the same time, it should be noted that in the recommendatory list of structural subdivisions of the district, Kyiv and Sevastopol district state administrations, which is the basic document for the formation of the DSA structure, does not have a land department, sector or administration at all. Although the list is of a recommendatory nature, and the structure of the local state administration and the status of its structural units are determined by the head of the administration, taking into account the requirements of current legislation (Pro mistsevi derzhavni: Zakon Ukrainy vid 09.04.1999 № 586-XIV), it seems strange that the list of powers enshrined in two basic regulatory legal acts is not reflected in the structure of the local executive body of the district level.

As already mentioned, the Land Code also contains a list of powers of the local state administration. However, despite the fact that several items from the lists of powers provided in the key regulatory legal acts for the DSA coincide, most of them are different (Table 1). 
We consider it expedient to amend the relevant regulatory legal acts in the direction of establishing in the legislation a single unified list of powers of the local executive authority, and to provide relevant unit in the structure of local state administration in accordance with the defined functions.

Table 1. Powers of the Local District Administration in the field of land management under various legislative acts

\begin{tabular}{|c|c|}
\hline Land Code of Ukraine & $\begin{array}{l}\text { Law of Ukraine } \\
\text { „On local state administrations” }\end{array}$ \\
\hline $\begin{array}{l}\text { The powers of local state administrations in } \\
\text { the field of land relations include: } \\
\text { - preparation of conclusions on the provi- } \\
\text { sion or withdrawal (redemption) of land } \\
\text { plots; } \\
\text { - redemption of land plots for public needs } \\
\text { within the limits determined by law; } \\
\text { - preparation of conclusions on the establi- } \\
\text { shment and change of boundaries of villages, } \\
\text { settlements, districts, districts in cities and } \\
\text { towns; } \\
\text { - control over the use of funds received in } \\
\text { order to compensate for losses of agricultural } \\
\text { and forestry production associated with the } \\
\text { withdrawal (redemption) of land; } \\
\text { - coordination of activities of land resources } \\
\text { state bodies ; } \\
\text { - solution of other issues in the field of land } \\
\text { relations in accordance with the law (Zeme- } \\
\text { lnyj kodeks Ukrainy: Zakon Ukrainy vid } \\
\text { 25.10.2001 № 2768-III). }\end{array}$ & $\begin{array}{l}\text { Powers in the field of use and protection of } \\
\text { lands, natural resources and environmental } \\
\text { protection } \\
\text { - develops, submits for approval to the rele- } \\
\text { vant council and ensures the implementation } \\
\text { of regional environmental programs; reports } \\
\text { to the relevant council on their implementa- } \\
\text { tion; makes proposals on state environmental } \\
\text { programs to the relevant authorities; } \\
\text { - takes measures to compensate for damage } \\
\text { caused by violations of environmental legi- } \\
\text { slation by enterprises, institutions, organiza- } \\
\text { tions and citizens; } \\
\text { - makes proposals to the relevant local go- } \\
\text { vernments on the organization of territories } \\
\text { and objects of the nature reserve fund of } \\
\text { local significance; } \\
\text { - informs the population about ecologically } \\
\text { hazardous accidents and situations, the state } \\
\text { of the environment, as well as about the } \\
\text { measures taken to improve it; } \\
\text { - organizes work to eliminate consequences } \\
\text { of ecological accidents, involves the enterpri- } \\
\text { ses, institutions, organizations in these } \\
\text { works, regardless of the form of ownership } \\
\text { and citizens; } \\
\text { - submits proposals in the manner prescri- } \\
\text { bed by law to suspend the activities of enter- } \\
\text { prises, institutions, organizations, regardless } \\
\text { of ownership, in case they violate the legisla- } \\
\text { tion on environmental protection and sanita- } \\
\text { ry rules; }\end{array}$ \\
\hline
\end{tabular}




\begin{tabular}{|l|l|}
\hline Land Code of Ukraine & $\begin{array}{l}\text { Law of Ukraine } \\
\text { „On local state administrations” }\end{array}$ \\
\hline & $\begin{array}{l}\text { - develops and ensures compliance with the } \\
\text { rules of using water intake facilities designed } \\
\text { to meet drinking, household and other needs } \\
\text { of the population, sanitary protection zones } \\
\text { of water supply sources; restricts or prohibits } \\
\text { the use of drinking water for industrial pur- } \\
\text { poses by enterprises; } \\
\text { - exercises control over the use of waste, } \\
\text { taking into account their resource value and } \\
\text { safety requirements for human health and } \\
\text { the environment and considers cases of ad- } \\
\text { ministrative offenses or submits their mate- } \\
\text { rials to other government agencies for } \\
\text { examination in case of waste legislation vio- } \\
\text { lation; } \\
\text { - exercises control over the provision of } \\
\text { unimpeded and free access of citizens to the } \\
\text { coast of water bodies and islands for general } \\
\text { water use in accordance with the law (Pro } \\
\text { mistsevi derzhavni: Zakon Ukrainy vid } \\
\text { 09.04.1999 № 586-XIV). }\end{array}$ \\
\hline
\end{tabular}

\section{ANALYSIS OF THE STRUCTURE OF THE DSA FOR LAND MANAGEMENT}

In the course of the research it was necessary to analyze the provisions of the DSA units for land management, as it is in them that the rules of law should be implemented (Pro zatverdzhennia rekomendatsijnykh perelikiv strukturnykh pidrozdiliv oblasnoi, Kyivs'koi ta Sevastopol's'koi mis'koi, rajonnoi, rajonnoi v mm. Kyievi ta Sevastopoli derzhavnykh administratsij: Postanova Kabinetu Ministriv Ukrainy vid 18.04.2012 № 606), and the functions to be detailed taking into account the specifics of a particular district. However, when analyzing the organizational structure of 40 district state administrations from 9 regions of Ukraine (Lviv, Odesa, Kharkiv, Kyiv, Donetsk, Kyiv, Cherkasy, Zaporizhzhia, Luhansk), it was revealed that the structure of any of the district state administrations does not include a department, board, sector, or at least a land specialist. In 
some administrations environmental functions are exercised in such departments as: "AIC and Environmental Protection Department "in Bilyaiv DSA of Odessa region, or "Ecology and AIC Department" in Obukhiv DSA of Kyiv region, "Urban Planning, Architecture, Ecology and Infrastructure Department" in Belovodsk Regional State Administration of Luhansk region. Proceeding from this, it is unclear how the DSAs fulfill the entire scope of authority for land management without having a relevant unit in their structure.

Supporters of this approach believe that such a situation is justified, because in order to prevent the dispersion of functions in the process of reforming districts as administrative-territorial units, district state administrations should be partially transformed or even cease to operate. But despite the resolution of the Verkhovna Rada of Ukraine "On the formation and liquidation of districts" dated July 17,2020 , the implementation of the second stage of the reform cannot yet be considered complete. Another argument in favor of this approach is the active processes of decentralization - the powers are delegated to local governments, while it is not supposed to form structural units of the DSA, which would duplicate the functions of village, town, city council of the united territorial community and its executive bodies whose jurisdiction limits completely coincide with the boundaries of the districts.

However, not all powers can be delegated, especially considering that land is a national wealth and the food, ecological and economic security of Ukraine depends on the quality of its management. Such powers may be delegated to the LG if there is a set of 2 conditions:

1) a specific public service can be provided as efficiently and economically as possible by the LG, and not by the executive authority body;

2) the delegation of powers of LG will make the public service more accessible and convenient for the end user.

If we consider the management model in which DSAs will not perform any powers in the field of land relations, then a necessary condition is that their functions are performed in full by other executive authorities and local governments. Meanwhile, the Law of Ukraine "On Local Government in Ukraine" does not contain a specific list of powers of LG bodies 
in the field of regulating land relations, but is limited to the general wording. In particular, the decision in accordance with the law on the regulation of land relations is attributed to the exclusive competence of local councils (Pro mistseve samovriaduvannia v Ukraini: Zakon Ukrainy vid 21.05.1997, No. 280/97-VR, Art. 26, $₫ 34$; Art. 43, item 21), as well as the issue of granting/revoking a permit for special use of natural resources of local significance, as well as the revocation of such a permit (Pro mistseve samovriaduvannia v Ukraini: Zakon Ukrainy vid 21.05.1997, No. 280/97VR, Art. 26, $\$ 36$; Art. 43, item 22) and decision-making on the organization of territories and objects of nature reserve fund of local significance and other territories subject to special protection (Pro mistseve samovriaduvannia v Ukraini: Zakon Ukrainy vid 21.05.1997, No. 280/97-VR, Art. $26, \S 37$; Art. 43 , item 24 ); and for village, settlement and city councils - also the approval of the land tax rates according to the Tax code of Ukraine (Pro mistseve samovriaduvannia v Ukraini: Zakon Ukrainy vid 21.05.1997 № 280/97-VR, Art. 26, \$35). A separate article of the law provides a list of powers (own and delegated) related to the jurisdiction of executive bodies of village, settlement, city councils in the field of regulation of land relations and environmental protection. At the same time, their own (selfgoverning) powers relate mainly to the preparation and submission to the council of proposals for setting the land tax rate, making decisions on the organization of territories and objects of nature reserves of local significance and other areas subject to special protection, projects of local environmental protection programs, etc., and delegated powers concern monitoring compliance with land and environmental legislation, resolving land disputes, coordinating the activities of local authorities of land resources, etc. (Pro mistseve samovriaduvannia v Ukraini: Zakon Ukrainy vid 21.05.1997, No. 280/97-VR, Art. 33).

However, the corresponding list is contained in the Land Code of Ukraine. Analysis of the structure of local governments showed that the Department of Land Resources (Baryshchiv village UTC, Kyiv region; Lyman town UTC, Donetsk region), or the department of land management, ecology, agro-industrial complex and urban planning (Shakhiv UTC, Donetsk region), Urban Planning, Communal Property and Land 
Relations Department (Kamyanka-Buzka UTC, Lviv Region), Urban Planning, Architecture and Land Relations Department (Chernihiv UTC, Zaporizhia Region) finds its place among the executive bodies of local councils. In addition, the processes of transferring agricultural lands outside settlements to the ownership of territorial communities are actively taking place. According to the monitoring of the process of power decentralization and reform of local government carried out by the Ministry of Community and Territorial Development, as of September 10, 2020, 646 UTCs got 1,450.8 thousand hectares of agricultural lands outside of the settlements into their ownership, which is $97.6 \%$ of the planned (Monitorynh protsesu detsentralizatsii vlady ta mistsevoho samovriaduvannia stanom na 10 veresnia 2020 roku).

Thus, the question arises, if the lands and the authority to manage them are transferred to local governments and the DSA does not actually have the appropriate structural units, then is it expedient to assign them functions to manage land relations at the legislative level?

\section{SOCIOLOGICAL STUDY OF THE DISTRIBUTION OF POWERS IN LAND MANAGEMENT}

In order to study the distribution of powers for land management at the local level, in March 2019 a sociological survey "Functional Analysis of Local Government Activities in the Context of Decentralization" was conducted. The following categories were respondents to the survey: employees of district state administrations and executive bodies of local councils of united territorial communities (hereinafter - UTC) of Orikhiv and Chernihiv districts of Zaporizhia region, as well as Belovodsk district of Luhansk region. The choice of executive authorities and local governments of these particular administrative-territorial units was made on the basis of the fact that at the time of the survey the process of uniting territorial communities in these regions was generally completed and stage of the redistribution of powers began. The total number of respondents was 161 people; summarized answers of respondents are given in table 2 . 
Table 2. Summary of respondents' answers to question on the distribution of powers in the field of land regulation and environmental protection, as a percentage of the total number of respondents

\begin{tabular}{|l|c|c|c|c|}
\hline \multicolumn{1}{|c|}{ Area of responsibility } & UTC & DSA & $\begin{array}{c}\text { Jointly } \\
\text { DSA } \\
\text { with } \\
\text { UTC }\end{array}$ & $\begin{array}{c}\text { Other } \\
\text { sub- } \\
\text { jects }\end{array}$ \\
\hline $\begin{array}{l}\text { Control of state - owned lands in the respective } \\
\text { territory }\end{array}$ & 41 & 25 & 25 & 4 \\
\hline $\begin{array}{l}\text { Implementation of state programs for environ- } \\
\text { mental protection }\end{array}$ & 23 & 17 & 39 & 12 \\
\hline $\begin{array}{l}\text { Approval of land management documentation on } \\
\text { the compliance of the specified documentation } \\
\text { with the legislation in the field of environmental } \\
\text { protection }\end{array}$ & 34 & 11 & 27 & 16 \\
\hline Land resources management & 56 & 11 & 18 & 11 \\
\hline $\begin{array}{l}\text { Organization and implementation of land mana- } \\
\text { gement, coordination of land management projects }\end{array}$ & 55 & 11 & 24 & 6 \\
\hline $\begin{array}{l}\text { Organization of control over compliance with } \\
\text { land and environmental legislation, use and pro- } \\
\text { tection of lands and natural resources }\end{array}$ & 34 & 7 & 40 & 13 \\
\hline $\begin{array}{l}\text { Conducting regulatory and expert and monetary } \\
\text { valuation of land }\end{array}$ & 30 & 6 & 19 & 37 \\
\hline Change in the purpose of land & 48 & 6 & 25 & 11 \\
\hline Resolution of land disputes & 45 & 6 & 34 & 11 \\
\hline $\begin{array}{l}\text { Execution of land management work, develop- } \\
\text { ment and implementation of land management } \\
\text { plans }\end{array}$ & 48 & 6 & 36 & 8 \\
\hline $\begin{array}{l}\text { Control over economic entities in the field of } \\
\text { waste management }\end{array}$ & 38 & 5 & 41 & 9 \\
\hline $\begin{array}{l}\text { Monitoring the compliance by legal entities and } \\
\text { individuals with the requirements in the field of } \\
\text { household and industrial waste management }\end{array}$ & 36 & 4 & 40 & 13 \\
\hline $\begin{array}{l}\text { Informing the population about the state of the } \\
\text { environment }\end{array}$ & 42 & 3 & 35 & 11 \\
\hline Identification of areas for waste disposal & 57 & 1 & 38 & 2 \\
\hline
\end{tabular}


As can be seen from the above data, the general trend of the survey is the willingness of local governments to take, and the DSA to give responsibility and powers in the field of land relations. This state of affairs is quite logical, because in the DSA there is nobody else to perform the relevant functions. We also consider it positive that the determination of the area for waste disposal should be carried out by local governments of the UTC (57\% of respondents), taking into account the opinions of local residents, because it is a matter of the state of the environment in the community, which directly affects its life. Accordingly, carrying out land management work, development and implementation of land management plans ( $48 \%$ of respondents) should be performed by structural units of executive bodies of local government, which are in charge of the lands of communities. But there are also controversial issues, among which the implementation of state programs for environmental protection, the process of which, logically, should be implemented, or at least controlled by the executive authority.

In addition, special attention should be paid to the answer option "jointly DSA with UTC", which contains a fairly high percentage of filling. Three points scored 40 percent or more - the organization of control over compliance with land and environmental legislation, use and protection of land, natural resources; control over economic entities in the field of waste management; control over the compliance by legal entities and individuals with the requirements in the field of household and industrial waste management. In all three cases, these issues relate to control functions.

In this context, we are talking about cooperation of local governments with district state administrations. However, taking into account the real situation, when the DSA has only nominally enshrined in the law functions that are not actually reflected in the structure, it is unclear how such cooperation can take place.

The study made it possible to identify a number of problems that hinder the cooperation between local executive authorities and local governments in the field of land relations:

- lack of cooperation mechanisms (organizational and legal basis of creation for the creation of collective bodies or commissions, their activities are not standardized; the system of planning their activity, coordination, reporting is not defined); 
- "blurring" of responsibility;

- double reporting, aggravating management information system;

- the presence of a number of exclusive powers of both the DSA and the LG bodies;

- unclear legal and regulatory framework.

An important aspect in the distribution of powers is the actual situation with the unification of communities in the district and the transfer of state-owned land to them. It is depending on these circumstances that we can talk about a variant of the model of distribution of responsibilities and the need for regulation at the district level in general.

The first option - if the unification of communities in the district took place and the land outside the settlements was transferred to the ownership of the community, and the district, in turn, is ready for further consolidation. We believe that in such circumstances the management, use and control of communal land resources is carried out by local government, and DSA exercises only exclusive powers to implement public policy: implementation and control over performing state target programs, coordination of community cooperation in the field of land relations and ecology, participation at control of common lands of communities. With such a model, it is expedient to transfer the relevant functions to the regional level of government and achieve a three-tier distribution of powers, i.e. to introduce a three-tier model "center - region - community". At the same time, legislative regulation of the powers of local government bodies will also require changes, for example, the clause on submitting proposals to the district council on establishing and changing the boundaries of villages, settlements and cities should be formulated differently if the relevant functionality is transferred to the region level.

The second option is when the process of unification or transfer of land to communal ownership continues (and can be called a transitional model). In such a situation, there is a need to leave to the DSA all the powers enshrined in legislation at this stage, but they should be unified, and it is advisable to make their list exhaustive. In this case, DSAs have a much wider range of powers than today, as all state-owned lands in the district are at their disposal. 


\section{CONCLUSIONS}

Thus, according to the results of the study, it is worth noting that an important element in the formation of amendments to the legislation in terms of distribution of powers in land management is to define the role of local executive authorities (DSA) so that it adequately reflects Ukrainian realities, namely either to foresee in the structure of the DSA land department and thus to establish compliance with current legislation; or amend the Land Code of Ukraine and the Law of Ukraine "On Local State Administrations", adjusting the sphere of competence of district state administrations for land management. Besides, it is necessary to standardize the management of state-owned lands in the district during the transition period at the stage of formation of united communities and reform of the district level of administrative-territorial organization of Ukraine.

We consider the development of a model of interaction between territorial communities regarding the control over common property lands, as well as solution of the necessary issue to attach land department and define its functional load in the structure of new DSAs created after the consolidation of districts as a promising direction.

\section{BIBLIOGRAPHY:}

Zemel'nyj kodeks Ukrainy [Land Code of Ukraine: Law of Ukraine]: Zakon Ukrainy vid 25.10.2001, No. 2768-III (Red. vid 16.07.2020). Downloaded from: https://zakon.rada. gov.ua/laws/show/2768-14\#Text.

Monitorynh protsesu detsentralizatsii vlady ta mistsevoho samovriaduvannia stanom na 10 veresnia 2020 roku [Monitoring of the process of decentralization of power and local government as of September 10, 2020]. Downloaded from: https://decentralization.gov.ua/uploads/library/file/593/\%D0\%9C\%D0\%BE\%D0\%BDi\%D1\%82 \%D0\%BE\%D1\%80\%D0\%B8\%D0\%BD\%D0\%B3_10.09.2020.pdf

Pro zatverdzhennia rekomendatsijnykh perelikiv strukturnykh pidrozdiliv oblasnoi, Kyivs'koi ta Sevastopol's'koi mis'koi, rajonnoi, rajonnoi v mm. Kyievi ta Sevastopoli derzhavnykh administratsij [On the approval of recommendatory lists of structural divisions of regional, Kiev and Sevastopol city, district, district in cities of Kyiv and Sevastopol state administrations]: Postanova Kabinetu Ministriv Ukrainy vid 
18.04.2012, No. 606 (Red. vid 05.03.2020). Downloaded from: https://zakon.rada.gov. ua/laws/show/606-2012-\%D0\%BF\#Text

Pro mistsevi derzhavni administratsii [On local state administrations: Law of Ukraine]:

Zakon Ukrainy vid 09.04.1999, No. 586-XIV (Red. vid 03.07.2020). Downloaded from: https://zakon.rada.gov.ua/laws/show/586-14\#Text

Pro mistseve samovriaduvannia v Ukraini [On local government in Ukraine: Law of Ukraine]: Zakon Ukrainy vid 21.05.1997, No. 280/97-VR (Red. vid 23.07.2020). Downloaded from: https://zakon.rada.gov.ua/laws/show/280/97-\%D0\%B2\%D1\%80\#Text 